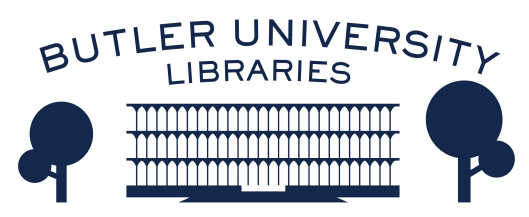

Journal of Hindu-Christian Studies

Volume 18

Article 9

January 2005

\title{
Mimamsa and Eucharist: Starting-Points for Postmodern Hindu- Christian Comparative Theology of Ritual
}

Michael T. McLaughlin

Follow this and additional works at: https://digitalcommons.butler.edu/jhcs

Part of the Religion Commons

\section{Recommended Citation}

McLaughlin, Michael T. (2005) "Mimamsa and Eucharist: Starting-Points for Postmodern Hindu-Christian Comparative Theology of Ritual," Journal of Hindu-Christian Studies: Vol. 18, Article 9.

Available at: https://doi.org/10.7825/2164-6279.1342

The Journal of Hindu-Christian Studies is a publication of the Society for Hindu-Christian Studies. The digital version is made available by Digital Commons @ Butler University. For questions about the Journal or the Society, please contact cbauman@butler.edu. For more information about Digital Commons @ Butler University, please contact digitalscholarship@butler.edu. 


\title{
Mimamsa and Eucharist: Starting-Points for Postmodern Hindu-Christian Comparative Theology of Ritual
}

\author{
Michael T. McLaughlin \\ Saint Leo University
}

MY interest in the topic of Mimamsa and ritual comes from an involvement with the kind of comparative theology that Francis Clooney has been pursuing. I have tried to comment a bit on some of his books, and so it was natural to take a look at his early book, a rather technical one, called Thinking Ritually. ${ }^{1}$ Clooney has been concerned with reading strategies in interpretation, and I would say that my reading skill when it comes to Mimamsa and studies of it is very rudimentary. Mimamsa deals with the way grammatical constructions determine the meaning of ritual injunctions. My initial idea was to try to write about this as a ritual ontology. This article will present a few general conjunctions on Mimamsa and Eucharist. The point is to stay as close as possible to the actual texts and practices. I believe this method of doing comparative theology of ritual by limited scale comparisons of actual rites and texts is more productive and revealing then vast generalizations about "the sacred" and "the sacrifice". The Mimamsa tradition occupies an unusual place in the history of Indian thought between "the sacred" and "the sacrifice". Is it a philosophy, or a theory of ritual, or an odd form of mysticism, or something of all three?

\section{Rituals in Transition and Negotiation: Homologies Sought}

On a more personal note, I was drawn to this topic as a result of my own frustrations with the way in which the Vatican II version of the Eucharist is sometimes celebrated and by my own desires to articulate what those frustrations mean. I would be an honorary Mimamsaka in my own concerns for the exact meaning of the rituals, the importance of sacred texts and their meaning, and the need for dignity and seriousness in continuing our centuries-old traditions of worship. There is a concern that the original Latin of the prayers is edited by translators to selectively eliminate language about bodily mortification, $\sin$, the devil, penance, and so on, in favor of more bland language about unity and love. If one agrees with Wittgenstein that "the limits of our language are the limits of our world", this is an important concern.

Will Hindu rituals once translated into English face the same pressures? I would argue that rituals have their own centuries-old language which preserves a conceptual framework in which transcendent realities can be named and experienced. In my own tradition, there has been some criticism that the revised rituals collapse vertical transcendence into horizontal

Dr. Michael McLaughlin guides numerous religion majors at St. Leo's University in Norfolk, Virginia. In 2003 he published Knowledge, Consciousness and Religious Conversion in Aurobindo and Lonergan with Gregorian University Press. His academic interests áre metaphysics, post-modernism, comparative theology, and theological foundations. 
socializing, though of course it is not a simple dichotomy. There is a value in having manuals for the performance of certain rituals, because ritual performance and beliefs are interlocking. This is something that the Mimamsa theologians of ancient times grasped as well. The rituals encode the beliefs in complex ways. Catholic believers can disagree over what the directives of General Instruction on the Roman Missal (GIRM) mean. Modern Catholic liturgists dispute with each other and with the Vatican over the meaning of symbolic gestures and try to have old gestures reworked to give new meanings, usually ones which emphasize the active role of the laity in the celebration. Dissident liturgists will say, for example, that the priest should not consume his host or wafer before distributing communion to the assembly; others will disagree. Some say the priest should not leave the sanctuary to go out into the space of the assembly; others say he can. Should the assembly stand for the Eucharistic prayer (early centuries) or kneel (medieval)?

\section{No Return to the Pre-modern Understandings of Ritual}

It has been clear for about 60 years, at least, and maybe for 100 that we cannot go back in Catholic Christianity to pre-modern ideas of ritual. Somehow it seems to me from my limited knowledge and awareness that Hindu scholars of liturgy will face the same issue. Ancient rituals must be made intelligible in any religion. The Mimamsa was dealing with this in its own time period.

We are caught up in what Foucault called discursive practices. Catholic liturgists are aware that the traditional language contains all sorts of explicit and implicit references to power and authority and hierarchy. There is no way around this but through this. Some tensions are good tensions.

Liturgists will argue over whether Eucharist is a noun or a verb, an act of consecrating bread and wine to make a presence present or a more diffuse event; a transubstantiation or a transignification. More technically, is Thomistic metaphysics or is Husserl's phenomenology as developed by Robert Sokolowski ${ }^{2}$ the best way to approach an understanding of real presence? Or is the whole thing an uncontainable instance of Derrida's khora or receptacle borrowed from Plato's Timeaus? Should one tap into the Neo-platonists as John Milbank $^{3}$ has done, though at a certain cost? Or should the whole thing be regarded as a mystification, a trance one should wake from, one which needs to be rethought in light of the global violence and poverty which the ritual must address to be what it should be? One scholar, William T. Cavanaugh, has written a book called Torture and Eucharist ${ }^{4}$, which, briefly, is about whether figures like Pinochet in Chile (1973-1990) should receive communion and whether the Church in its ritual symbolization of communio, can form a counter society, an alternative body, to the state.

To the extent that some Hindu rituals tie into a caste system and exist in the midst of unintegrated tribal peoples, will new forms of Hinduism break with the past to enact a more egalitarian view of the world? Is "egalitarian" the wrong word, because it is too secular?

What follows are a few suggested homologies which reading about Mimamsa has provoked in me as a theologian interested in comparative theology and specifically in a comparative theology of ritual. One can visit the world view of Mimamsa, at least through the texts, to come back and see one's own ritual ontology with new eyes. ${ }^{5}$

\section{Twelve Possible Starting Points for Comparative Theology of Ritual}

\section{The Notion of Sacrifice}

It strikes me that both have a certain notion of sacrifice, though in both cases it is subtle. Broadly speaking the idea is that one destroys something in the context of offering that something to a higher entity than oneself in order to unite oneself with that 
higher realm. In general, what interested me is that this unity is not merely moral but ontological, at the level of being.

This is true both for Mimamsa and Eucharist. In Eucharist, it is normally worked out through an idea that the creature is recreated or restored in his or her being by graces received in the celebration. More specifically, the distance created by original sin and by personal sins is overcome. Mimamsa also seeks the fruit (phala) of the sacrifice, as I will touch on later.

\section{The Sacred Order Must be Followed}

Performing the sacrifice according to an ancient and fixed pattern is more important than the results and the performer: The performer submits to an order which is greater than himself. Clooney says strikingly at one point, "The event of the sacrifice is primary. Its action is the referent of all value and significance. A world of which the sacrifice is the center is not the world of ordinary experience." The central element of the Veda is the collection of injunctions (vidhi) to perform specific ritual actions such as sacrifice. ${ }^{7}$. Analysis of the verbal expression of the injunction is an important issue. "The Veda is eternal and absolute. It does not express the will of anyone even God. The Vedic injunctions have no other basis than the Veda itself which God remembers at the start of world aeons and reveals to human beings." $\dot{8}$

\section{The Performer is Specified}

The performer of the sacrifice is not just anyone but rather the one clearly designated by the community as the one qualified to perform it. ${ }^{9} \quad$ In the Eucharist, this entails ordination which is understood as imparting a permanent character to the one ordained. You cannot be unordained once you have been ordained. Edgerton ${ }^{10}$ indicates that in Mimamsa permanent rites (nityani) must be performed one's whole life long even if bodily strength is lacking to perform them completely. ${ }^{11}$

\section{Homologies are Limited}

Mimamsa, as is well known, has a number of unusual features which make it quite different from the Eucharist. There is very little focus on the gods as such ${ }^{12}$. Clooney can speak of a non-supernatural transcendence and clarifies this odd designation by saying that "Transcendence "occurs" when the performer finds himself in a world which accounts for his viewpoint without making himself the center of the world." ${ }^{\prime 13}$ It is well known that in Mimamsa the gods are merely secondary elements of the ritual. This is in significant contrast to the Eucharist where the Holy Spirit is invoked to "descend" upon the gifts of bread and wine and transform them (this is especially clear in the Syrian Rite). The Purva Mimamsa Sutras of Jaimini do not use the words atman and Brahman as metaphysical elements. ${ }^{14}$

\section{Internal Order is Meaningful}

Mimamsa had a great deal of concern for the internal order and structure of the ritual, i.e. ontology of ritual language and gesture. The six pramanas or modes of evidence are used to determine that one thing is subsidiary to another and related to it in dependence. ${ }^{15}$ This is something that is also true of the Eucharist. The sequence of actions and subactions in the celebration is important, the spontaneity of the prayers used is very limited. There seems to be a way in which for both Mimamsa and Eucharist the designated celebrant surrenders himself to the directions or rubrics for the ritual in order to perform it. Many gestures are prescribed. Apurva in Mimamsa, as Edgerton notes, is the "mysterious transcendental effect" generated by the correctly performed ritual act.

\section{An Ontology of Ritual Economics}

Someone has to pay for rituals, and this practice of payment is inevitably part of their meaning. The fact that the ritual is paid for by someone has to be part of its inscription in the whole system of meaning. In Mimamsa the person who pays for the performance of the sacrifice, the Yajamana, receives the fruits of $\mathrm{it}^{16}$; in the Catholic 
Eucharist, an offering is requested if one wishes to have a Mass said for the repose of the soul of a loved one or anyone else, but it is forbidden for the priest to insist on a financial contribution. A poor person who lacks the $\$ 10$ or so for the stipend is still entitled by canon law to have the Mass said. In many Catholic churches, these Masses are reserved for months in advance, and sometimes the Mass can be said only by a missionary in some other part of the world.

\section{Ritual is an Intentional Act ${ }^{17}$}

Ritual intends to get a result, to deliver on the promise which accompanied the injunction to perform the ritual. Still, it would be reductionist for the ritual scholar to attribute either the Hindu's desire for the fruits of sacrifice or the Christian's desire for the fruits of the sacrifice to a mere magical consciousness which seeks to control the deity. Clooney in his Thinking Ritually is clearly trying to get beyond unwarranted uses of terms like magic. The believer perhaps understands the sacrifice as offering; an offering is an offering, and it can be turned down. It is a gesture. The economy of the gesture is subtle; it is not one of exchange. In passing, I would suggest that reading Derrida and his commentators on gift makes it clear that anything in the realm of "symbolic exchange", a term which would itself have to be examined, is enormously complex and open ended. In performing the ritual one makes a kind of gift to the gods. It is not a payment for services rendered either past or future and yet the ritual performer still wants something. Minimally, the performer wants at least some sign of recognition of his or her gesture. Christian theology has often focused around Abraham's obedience in being willing to sacrifice Isaac as a paradigm case; in doing do he would seem to be sacrificing the whole future of the covenant relationship since there will be no more sons to carry on Abraham's name and memory. ${ }^{18}$ As is well known, Abraham becomes the paradigm of faith lived out in fear and trembling. Jesus is understood analogously to Isaac as another only begotten son sent from the Father's world to ours and he too will be obedient to the point of death.

\section{Rituals become "Obsolete:" Linguistic \\ Framework Breaks Down}

It is also possible for rituals to become unintelligible. Mimamsa was concerned with making intelligible certain rites which had become unintelligible. In effect, rituals can become erased from a local culture when their meaning is occluded. In early Christianity, there was tremendous emphasis on the rites of initiation. Much of the language was influenced by the language of initiation into the Greek mystery cults, but the ultimate goal was receiving the light of Christ.

\section{Rituals are Commanded}

The Eucharist is understood as a ritual commanded by Jesus at the Last Supper: "do this in memory of me". In the same way, as Edgerton helps us see, the Vedic sacrifices as understood by Mimamsa as compelled by the word's efficient force (inherent in the optative ending) ${ }^{19}$, and so since by injunctions "...he shall sacrifice etc. is enjoined with a view to heaven etc., it is establist (sic) that the sacrifice etc. is a matter of duty, because it is enjoined by the Veda with a view to a useful end". ${ }^{20}$ In both cases, there is a scriptural foundation which authorizes and commands the practice.

\section{Rituals can Mingle or Collide}

There was an account recently posted on the Hindu-Christian Studies Discussion List involving some Hindus performing a religious ceremony at the church at Lourdes, France, the famous Marian shrine at the place where Our Lady is said to have appeared. I commented at the time that I found it rather unsettling since it was not clear to me what the participants intended to do. Clearly they were doing more than just renting the space in order to do a ritual. Catholics understand their churches as a sacred space which is consecrated by means of a fairly elaborate ritual and is thus set apart from the profane space around it. The 
altar is also sacred and contains the relics of a saint which are permanently embedded in it. It would be unfair to say that the Hindus wanted to desecrate the ritual space of the Catholics, but clearly many Catholics would believe that Hindus were in the wrong symbolic or ritual space. Catholics would not ask to celebrate Eucharist in a Hindu temple for similar reasons. We do not allow Wiccan rituals or Druid rituals or other nonChristian rituals to be celebrated, unlike what has occasionally happened on the fringes of some other Christian churches.

This raises the question of whether it is possible or even desirable to create a hybrid religious space which is neither Hindu nor Christian. Can we do so without transgressing both or does that put us into the realm of an ill-conceived syncretism? Hybridity is favored by some cultural theorists. To illustrate, I once saw a photo of a Catholic Mass being celebrated in which a statue of the Buddha had been placed on top of the altar not far from where the bread and the chalice of wine were being prepared. But what does this mean, this sort of juxtaposition of symbols? Is it meaningless? Is the Buddha merely along for the ritual ride like a set of rosary beads hanging from the rear view mirror? I am not sure. Is he there like the relics of a Christian saint might be there ${ }^{21}$ Should the Buddha be asked to leave? ${ }^{22}$

\section{Ritual Participants Can Mingle, Bond or Collide}

Any discussion of ritual and sacred spaces today would have to note that these also become places of protest and in some cases even of violence. These protests can be enacted between religions or within religions (such as protests around clergy sexual abuse even during a liturgy) or between believers and social activists, such as the 1989 invasion of the St. Patrick's Cathedral in New York City by condom throwing AIDS activists ${ }^{23}$. While many scholars have presented the encounter between religions and their devotees as fairly irenic, emphasizing mutual learning and sharing, I would also emphasize the unpleasant side of conflict that sometimes occurs in the ritual sphere.

Some feminists have invented new rituals or revived ancient ones, such as blessing after childbirth or a healing ritual after rape. Whether authorities will ever recognize these rituals and allow them to enter the official space of the sacred is an open question. Indian Dalit Christians in their own sphere may request adaptations of received rituals if they believe that existing rituals reinforce caste distinctions. ${ }^{24}$

\section{Ritual Knowing: Scholars Can Mingle, Observe or Join ${ }^{25}$}

In an indirect way, the Mimamsa focus on doing the rituals correctly and with a certain detachment brings me to Thomas Forsthoefel's recent book Knowing Beyond Knowledge $e^{26}$ which seems to me to be very valuable. To oversimplify, he is concerned with some fairly sophisticated issues in epistemology having to do with whether religious knowing is primarily an internal experience dealing with intuitions, concepts and inferences and "experiences" or whether it is primarily external ${ }^{27}$ dealing with the social practices and rituals which put one in the correct frame of mind to have certain experiences (anubhava) or whether such knowing is really a combination of both. For example, we might tend to think of classical Advaita as predominantly internalist ${ }^{28}$ and see rituals as something that the realized person goes beyond, not unlike the remark of Nietzsche that "Christianity is Platonism" for the masses, a remark that also devalues symbolic and ritual mediations. Can a scholar understand religious experiences of another religion from the inside or only mimic such an experience? Thomas Forsthoefel has indicated that this has something to do with being socialized into a whole series of practices. Can a scholar understand Advaita without having the experiences of realization? Is it possible to write intelligently about rituals and their meaning from a safe distance, that is, without participating in them? What does it mean that realized persons (jivan-mukta), who 
have been transformed by the transcendent, are so few? ${ }^{29}$

\section{Conclusion}

This article has been an initial attempt to think together structures of Mimamsa and Eucharist in order to see what kind of comparative theology of ritual would emerge in a postmodern context which does not privilege either Christian or Hindu discourse but seeks to mediate between them. Commonalities were found around the notion of sacrifice, sacred order, an authorized performer, an economic dimension, a command to perform the ritual, and the question of the boundaries within which the ritual are performed. Questions were raised about whether it is possible to understand a ritual outside of the desire for and experience of the transformative experience which ritual participants seek. Is there any kind of neutral observer stance which is not at least partially distorting? At the same time, the limits were seen in the homologies that can be brought to light. This problem is related to larger issues in comparative theology about the use of bridge terms such as God as "maker" (not creator) which try to bring theologies together. ${ }^{30}$ Unlike Francis Clooney in his challenging Hindu God, Christian God, I would see comparative theology as a separate project from Christian theology of religions and not as one which subsumes traditional Christian theology into itself.

From the Christian side, it is certainly possible to see in the language of Mimamsa theology, "a ray of the truth" which enlightens all people and perhaps, in the sacrificial ritual, an intimation of the Spirit who descended at Pentecost to unite the many languages of the earth (Acts 2: 4).

\footnotetext{
Notes

${ }^{1}$ Francis X. Clooney, Thinking Ritually: Rediscovering the Purva Mimamsa of Jaimini. vol.17, De Nobili Research Series, ed. by G. Oberhammer. (Vienna: Indological Institute of
}

the University of Vienna, 1990.) In addition to Clooney's book, the most accessible and available source for the texts seems to be Franklin Edgerton, The Mimamsa Nyaya Prasaka or Apadevi: A Treatise on the Mimamsa System by Apadeva (New Haven: Yale University Press, 1929). There are other editions such as those edited by G. Jha. I have omitted diacritical marks. For background, Jan Gonda, The Ritual Sutras (Wiesbaden: Otto Harrasowitz , 1977) and J. C. Heesterman, The Broken World of Sacrifice: An Essay in Ancient Indian Ritual (Chicago: Univ. of Chicago Press, 1993).

${ }^{2}$ In Sokolowski's theology of disclosure, the deeper meaning of the Eucharist does not get lost in sheer absence and mere symbolism (p.213). The Eucharist re-enacts a historical act accomplished by a God who transcends nature. Sokolowski distinguishes this concept of God from that found in the mystery cults by some historians of religion. (163). Robert Sokolowski, Eucharistic Presence: $A$ Study in the Theology of Disclosure (Washington, D.C: CUA Press, 1994).

${ }^{3}$ John Milbank, Being Reconciled: Ontology and Pardon (London-New York, N.Y.: Routledge, 2003). I am also indebted to my friend, Prof. James K. A. Smith at Calvin College (AAR 2004) for some of his reflections on Milbank.

${ }^{4}$ William T. Cavanaugh, Torture and Eucharist: Theology, Politics, \& the Body of Christ (Malden, MA.-Oxford: Blackwell, 1998). See also Kenan B. Osborne, Christian Sacraments in a Postmodern.World: A Theology for the Third Millenium (Mahwah, N. J. :Paulist, 1999), David Power, Sacrament; The Language of God's Giving (New York, N.Y.: Crossroad, 1999) and Louis-Marie Chauvet, Symbol and Sacrament :A Sacramental Reinterpretation of Christian Existence (Collegeville, MN.: Liturgical Press, 1995). I do not try to discuss the controverted issue of ritual inculturation and its limits which scholars such as Anscar Chapungo and others have addressed.

${ }^{5}$ I have relied more on the older and simpler study and comments of Edgerton than on Francis Clooney for the overview here.

${ }^{6}$ Clooney, p. 149.

${ }^{7}$ Edgerton, p. 5. 
${ }^{8}$ Edgerton, p.6.

${ }^{9}$ This is the fourth kind of injunction, adhikara. See Edgerton, p.11.

${ }^{10}$ Edgerton, p.12.

${ }^{11}$ The Brahmin seems, at some point in the tradition, to become the silent overseer of the rites performed by the specialized officiants. See Heesterman, p.150. I have not been able to take into consideration Heesterman's thesis about the internalization of sacrifice.

${ }^{12}$ See Francis X. Clooney, "What's a God? The Quest for the right understanding of the Devata in Brahmanical Ritual Theory (mimamsa)". International Journal of Hindu Studies 1:2 (1997) 337-385. For a brief overview of Mimamsa see Francis X. Clooney, "Why the Veda has no Author: Language as Ritual in Early Mimamsa and Post-Modern Theology" Journal of the American Academy of Religion 50:4 (1988):659-683. The early Mimamsa school dates to a text by Jaimini, the Purva Mimamsa Sutras, which has been dated at approximately $200 \mathrm{BCE}$. There are whole series of commentaries on this text stretching over centuries. Jain and Buddhist skepticism over the value Hindu sacrifices is part of the debate that the commentarial tradition is dealing with (p.663).

${ }^{13}$ Clooney, p.160.

${ }^{14}$ Clooney, p.204.

${ }^{15}$ These pramanas are direct statement (sruti), word-meaning (linga), syntactic connection (vakya), context (prakarana), position (sthana) and name (samakya). (Edgerton, 9)

${ }^{16}$ I owe this and other clarifications to Francis Clooney.

${ }^{17}$ See also Heesterman, pp.77, 85. Christianity does not have much in the way of domestic rites. See Gonda, Jan Gonda, The Ritual Sutras, $A$ History of Indian Literature, Wiesbaden, 1977, vol. 1, fasc. 2 Grhyasutras, p. $446 \mathrm{f}$. and $556 \mathrm{f}$. See also, Paul B. Courtright, "Looking at the Eucharist through the lens of Puja: An exploration in the comparative study of religion
", International Journal of Hindu Studies 2 (1998):423-440.

${ }^{18}$ See also David Power, 278 for an overview of the economy of gift in sacramental theology and also the more technical article, "On the Gift: A Discussion between Jacques Derrida and Jean Luc Marion"- Moderated by Richard Kearney- in the volume, John D. Caputo and Michael J. Scanlon eds., God, the Gift and Postmodernism (Indiana University Press: BloomingtonIndianapolis, 1999) pp.54-78 and especially pp. 59-69. All three: Kearney, Marion, and Derrida participate in this discussion.

${ }^{19}$ Edgerton, p.179

${ }^{20}$ Edgerton, p.188. I am simplifying the discussion given in the text.

${ }^{21}$ When this paper was originally given at the American Academy of Religion (Nov. 2004), an attentive scholar in the audience asked whether the criteria for such a "hybrid" liturgy could not be pragmatic or aesthetic. I replied at the time that perhaps that might be a kind of "Episcopalian" rather than a Catholic solution to the issue. I meant to indicate that the Catholic Church exercises a much stricter doctrinal control over liturgies and indeed over what kinds of images are allowed to be displayed in churches. Normally only images of those officially declared to be saints or blessed can be displayed for veneration by the faithful. Of course, Pope John Paul II has changed the dynamic by canonizing vast numbers of saints, especially lay saints, in what amounts to an explosion of available icons. I do not presume to speak for Episcopalian liturgists, of course.

${ }^{22}$ For the unpredictability of the unauthorized hybridity that actually occurs on the ground, see Selva J. Raj, "Dialogue 'On the Ground': The Complicated Identities and Complex Negotiations of Catholics and Hindus in Southern India," Journal of Hindu-Christian Studies 17(2004):33-44 where he shows that the popular mind in fact has no problem mixing and matching rituals, practices, and devotions across Christian and Hindu borders.

${ }^{23}$ The Cardinal of New York at the time, John O'Connor, also visited AIDS patients in the hospital, volunteering to empty bed pans and wash their hair. It is said that many had no idea 
who he was because they were so ill. One hopes that liturgies do not become a site for disruptive protests which disturb and possibly anger large numbers of those in the congregation, as happened recently with the rainbow sash groups in Chicago. Certain kinds of protest at ritual sites are a form of psychological violence on both sides. We live in a time of terrorism. Is it too much to suggest that religious people of all kinds should not encourage violent interactions inside or outside of the boundaries of their own life-worlds?

${ }^{24}$ See Mathew N. Schmalz, "A Bibliographic Essay on Hindu and Christian Dalit Religiosity," Journal of Hindu-Christian Studies 17 (2004):55-64 especially at p. 60 where lower caste opposition to adaptations made in favor of Brahmin religiosity is discussed.

${ }^{25}$ This falls under the topic of multiple religious belonging about which Catherine Cornille and others have written. It is probably true to say that many scholars have experienced living within more than one tradition to some degree or other.

${ }^{26}$ Thomas Forsthoefel, Knowing Beyond Knowledge: Episternologies of Religious Experience in Classical and Modern Advaita, (Aldershot, Hampshire: Ashgate, 2002).

${ }^{27}$ As a point of reference for the terminology, see Laurence Bonjour, "Externalism/Internalism " in J. Dancy and E. Sosa, eds. A Companion to Epistemology (Oxford and Cambridge, MA: Blackwell, 1982), pp. 132-136.

${ }^{28}$ Forsthoefel, pp. 41-42, 45 .

${ }^{29}$ Andrew O. Fort and Patricia Y. Mumme, eds., Living Liberation in Hindu Thought (Albany, NY.: SUNY Press, 1997). The introduction by Andrew Fort (pp.1-13) gives an overview of the whole question. See also Arvind Sharma, "Jivanmukti in Neo-Hinduism: the case of Ramana Maharisi," Asian Philosophy 9:2 (1999):93-105.

${ }^{30}$ See my "Hindu God, Christian God: Questions of Theological Method", unpublished paper, given at the Catholic Theological Society. meeting, Reston, Va., 2004. It should be clear that I am not proposing to replace Christian theology with comparative theology. On the other hand, as in my earlier work, Knowledge, Consciousness and Religious Conversion in
Lonergan and Aurobindo (Gregorian University Press: Rome, 2003), I am trying to let each side express the full range of its conceptual resources (epistemological, metaphysical and experiential) for describing the Real or the Absolute. 